Article

\title{
Implementation of Sustainable Tourism in the German Alps: A Case Study
}

\author{
Ivan Paunović ${ }^{1,2, *}$ and Verka Jovanović ${ }^{1}$ \\ 1 Department for Tourism and Hospitality Management, Singidunum University, Danijelova 32, \\ Belgrade 11000, Serbia; vjovanovic@singidunum.ac.rs \\ 2 Tourism Chair/Center for Entrepreneurship, Catholic University of Eichstätt-Ingolstadt, \\ Pater-Philipp-Jeningen-Platz 2, 85072 Eichstätt, Germany \\ * Correspondence: ivan.paunovic.12@singimail.rs or paun.bg@gmail.com or ivan.paunovic@ku.de; \\ Tel.: +381-6364-6448
}

Academic Editors: Riccardo Beltramo, Pietro Beritelli, Pierre Torrente, Gabriela Tigu and Stefano Duglio Received: 17 December 2016; Accepted: 1 February 2017; Published: 8 February 2017

\begin{abstract}
What are the processes behind efforts for more sustainable mountain destinations in the German Alps and what are the views of different tourism stakeholders on these processes? The research deals both with threats pushing the agenda of sustainable development (such as climate change and depletion of resources), indicators of sustainable tourism (to measure the scope of change), as well as cross-border cooperation and stakeholder engagement in the German Alps. The data was collected through 30 interviews with individuals dealing with tourism development and sustainable tourism development in the German Alps. The findings suggest that a holistic approach and collection and dissemination of data and knowledge on sustainability are the basis for developing sustainable mountain tourism. Implementation and monitoring should focus on specific flagship sustainable tourism products, as well as on a destination in a broader sense and the sustainable tourism market. Three themes emerged as important for implementation of sustainable tourism in the German Alps: indicators of sustainable tourism, cross-border cooperation and stakeholder engagement.
\end{abstract}

Keywords: sustainability; mountain tourism; destination planning; regional development; climate change; resources; stakeholders; cross-border cooperation

\section{Introduction}

The focus of the research was identifying different measures, different styles and approaches to the challenges of sustainability in order to promote different destination governance modes and support policy innovation through a diffusion of best practices in the German Alps. In this sense, Hall [1] sees governance and change frameworks as prerequisites for policy learning and change in general. The three main themes for implementation of sustainable tourism, which emerged in the research, were: indicators of sustainable development (and sustainable tourism), cross-border cooperation and tourism stakeholders. The main objective of the research follows the recommendations of Diaz and Rodriguez, namely, that future studies in sustainable tourism should focus on stakeholders' views of sustainable tourism in different types of destinations using a qualitative methodology [2].

Sustainability has become a central issue for the future of tourism planning and development $[3,4]$, developing from the early concepts of the triple bottom line (economy, society, environment) that influenced sustainable tourism in the 1980s [5,6], all the way to the quadruple bottom line, where authors like Orlovic-Lovren et al. [7] extend the triple bottom line to include more recent developments, such as climate change, as a reflection of the Davos Declaration [8]. Accentuating only one aspect (economic growth with solely quantitative measures) is one of the main contemporary obstacles to making tourism more sustainable and enabling qualitative destination development $[9,10]$. 
Sustainable tourism is theoretically founded on a holistic approach and a knowledge-based platform, which means that all forms and scales of tourism should be considered, and the approaches adapted respectively [11]. In this sense, science must help determine whether or not a destination is sustainable, or the extent to which it is sustainable. This is achieved by establishing, measuring and controlling the indicators of sustainable development, which are a scientific way of informing decision makers on important sustainability issues. However, this is easier said than done, because sustainable tourism research is still in the early stages of identifying the major issues and corresponding changes needed to make tourism more sustainable [12], such as crisis management (resilience), climate change as a part of sustainable destination planning, and carrying capacity $[13,14]$.

Mountains are one of the most important natural attractions for contemporary tourism, through their geographic space characteristics as well as climate and land forms [15-17]. Mountains also play a very important role in broader sustainability because of their importance in the global water cycle [3]. Namely, the headwater sites for most of the major river systems are usually located in the mountains, which also influences the lowland regions. Apart from the geographic dimension, sustainability in mountain regions often deals with strong political dimensions, in the sense that arbitrary political borders often ignore geographic, cultural and biological boundaries [18], as well as because the main resources around which a tourism industry develops in the mountains are publicly owned and managed [19]. Many of the mountain areas are protected by government as biosphere reserves, nature parks or national parks for their natural and cultural capital [13]. Therefore, the carrying capacities of the mountain ecosystems are rather limited, which is why any excessive economic activity in these areas, including tourism, raises much concern about the impact on the cultural and natural environment, as well as about abiding by environmental laws.

\section{Literature Review}

Sustainable development can be defined as a concept of introducing structural change to a society so that the development does not physically and socially overwhelm the local community in the sense that it threatens growth through social unrest, environmental pollution or resource depletion [20-22]. However, there is criticism of sustainable development that it represents a utopia, where most obvious problems are a lack of stakeholder involvement, as well as a lack of priority on economic aspects [23]. Nevertheless, sustainability and sustainable development as concepts have managed to survive almost three decades of academic criticism, starting from the Brundtland Report in 1987, and have become an important policy framework in tourism $[5,24]$. Keeping in mind that tourism involves the interaction of tourists with the local economy, community and the environment, sustainable development is a very useful and applicable concept for dealing with changes in tourism development [20].

Mountains are a valuable natural asset of which the tourism industry very often makes extensive use [25]. In this sense, it is indicative that $10 \%$ of tourist hotspots worldwide are developing mountain tourism, and in the Alps alone, there are more than 50 medium or large tourist hotspots with mountain tourism [26]. However, environmental protection in the mountain regions also has a long-rooted tradition. One of the most famous historic examples of government leadership regarding environmental protection is the establishment of the Rocky Mountain Park in 1887 [27]. The Quebec Declaration on Ecotourism [28] is an important document that recognizes the need to support the implementation of policies regarding ecotourism, especially in countries with mountain areas. In this sense, mountain resorts have to respond to the changing market, environmental and social conditions and expand and improve their offer.

On the European Union (EU) policy level (which significantly affects the German Alps), the integration of the principles of sustainable development in EU treaties created an institutional framework that later enabled tourism governance and the creation of tourism policy [29]. After that, the most important processes of governance in EU tourism (development of Agenda 21 for tourism, definition and use of indicators and definition and use of satellite accounts) were conducted by European Commission (EC) working groups, and later adopted through EC communications. It is 
important to note here that the complexity of the issues related to sustainable tourism usually requires a very broad response not confined only by tourism-specific governance [30], but bearing in mind broader sustainability issues and policy agendas.

Sustainability in tourism has been adopted on the abstract strategic level, but is poorly implemented and operationalized [31]. As Ruhanen [32] notes, top-down directives from the state and federal levels imply that local governments should assume responsibility for dealing with sustainable tourism. In reality, this is a new role with which many local governments have problems dealing because of the lack of knowledge and skills for implementing sustainability in practice. Therefore, the author calls for filling this gap by educating planners on how to implement sustainability, before addressing the local community capacity for participation in the process. In the process of mainstreaming sustainable tourism development as a concept, three groups of actors are identified: change agents (government, industry, education), opinion leaders (directors, community leaders, entrepreneurs, friends), and social networks (colleagues and neighbours) [33].

Implementation of sustainable tourism must involve communication about sustainable tourism towards local stakeholders and citizens or the local population [34], as well as towards consumers or tourists [35]. Both implementation and communication build upon the previously developed indicators of sustainable development, as a prerequisite. Communication about indicators of sustainable development/tourism is especially tricky because by introducing the type of governance through indicators, communication goes from purely political/government communication to partly science communication. This is an important notion because science communication processes tend to be complex and uncertain [36], unlike political communication. Therefore, a two-way learning partnership needs to be created via various tools between experts and decision makers and all other stakeholders which are involved and affected [37]. For example, Hak et al. [38] suggest using the indicator policy factsheets as short summaries, easily comprehendible and suitable for rapid use by politicians.

There are many factors that can present an obstacle for tourism development: lack of attractions, lack of demand, local resistance to change, climate change, but also political borders [39]. In this sense, cross-border regions are regions where neighbouring countries meet, where the presence of the political border influences all walks of life and where a shared sense of economic and social periphery exists [40]. Cross-border cooperation is very important in order to enable the development of the tourist destinations based on consumption patterns [41], as well as mutual cooperation and partnerships [39], rather than on administrative borders [42]. This need especially becomes obvious in a situation when interests at the national level of the two neighbouring countries do not coincide with the need for cross-border collaboration at the regional level [43]. However, on the EU level, it has been recognized that sustainability depends on the cooperation of the neighbouring countries, which is why cross-border cooperation has been used as an important tool to promote and advance sustainability principles across the EU [44]. Freeman [45] defines a stakeholder as any individual or group that can affect or is affected by achievement of the organization's objectives. Going further from this general definition, Jamal and Getz [46] note that the right to be involved in the tourism decision-making process must lie with the resources and skills for participation. In this sense, stakeholder involvement is both a critical part of sustainable tourism development [47] and a major obstacle, as there is little academic clarity on how to improve stakeholder participation, making it more effective and efficient [34]. Pechlaner et al. [48] propose giving so-called "secondary stakeholders" in Bavaria a key role in creating future tourism products. Similarly, many regional development programs (LEADER—Liaison entre actions de développement de l'économie rurale, RM-Regional management) in Bavaria, have two main characteristics: the first one is a bottom-up approach, where goals are generated through discussions with local stakeholders; and the second one is that "tourism" and "recreation" are among the most frequently named fields of action in this programs. After all, tourism destination is an elusive term and it represents an amalgam of different businesses and people sharing the common interest of local community development [49]. 


\section{Materials and Methods}

During the last several decades, interviews have remained the main research method within the social sciences [50]. This is because interviews are, as Smith [51] points out, about understanding how people think and feel about certain issues and experiences. This means that they are usually not conducted on any kind of representative sample and, as such, the results of the interviews cannot be generalized beyond the subjects interviewed. However, according to authors, carefully conducted personal interviews can, in certain situations, provide richer data and greater insights into phenomena compared to questionnaires. This is one reason why the study used an interpretative, qualitative, interview research methodology. It was considered suitable for providing rich narrative about wider context in which sustainable tourism and governance take place in the German Alps as a unit of research. The primary data were collected between October 2015 and January 2016, through 30 semi-structured, in-depth interviews. The interview process entailed sending the questions in advance, in preparation for the interview (in the Annex 1), and the interviews were then conducted over the telephone, at the appointed time in German. Each interview lasted around $30 \mathrm{~min}$, which was more than enough time given that the interviewees had prepared themselves to answer the questions. The interviewees were mostly directors and managers of tourism organisations (12), then managers of regional development organizations (4), nature park and national park administrators (3), thematic routes managers (3), cable car directors (4), as well as one interviewee from the Ministry of Economy (1), an international organization in the Alps (1), a certification body (1) and a large attraction (1). Secondary data consisted of academic literature in the field, as well as reports and other materials recommended by the interviewees during the course of the conversation. Initially, a group of contacts was identified through official websites. After the initial contacting, it became clear which stakeholders were interested in the subject, which were less so, and further contacts were recommended in order to obtain additional in-depth data from the most knowledgeable persons on the subject of sustainable tourism.

\section{Results}

\subsection{The Case of the German Alps and Strengths, Weaknesses, Opportunities and Threats (SWOT) Analysis}

The German Alps are one of the most tourism-intensive regions in Europe. They are mostly located in the Bavarian Alps to the east, and a small portion to the west belongs to the state of Baden-Würtemberg. Bordered to the south with Austria and Switzerland, and to the north with the city of Munich, it represents one of the oldest tourism regions in Europe, with a 150-year-old tourism industry tradition. Apart from that, nature protection history is very old, more than one hundred years. This means that the tourism experience is authentic and perceived as an important part of the identity of local communities.

The German Alps are actually more of a foothills of the Alps than a classic high-mountain region. As such, they are increasingly dealing with climate change issues, because there are more and more warm rainfalls, and less and less snow. Due to ever-increasing skiing days, the communities are actively looking for ways to reorient their activities. Some communities are investing considerable money, time and effort to improve the sustainability of tourism through introducing change both to their winter and summer tourism. The snow machines are barely rentable, which is why ski tourism is an increasingly less-profitable option for the German Alps compared to France and Austria. However, ski destinations are trying to inform guests online (webcams, weather reports) so they can book on short notice when the weather is good. This also fits well with the trend towards shorter vacations in the German market.

An advantage of the German Alps, as a part of the Alps as a region, is that there are organizations such as Alliance in the Alps (that base their work on the Alpine Convention and sustainable development) and Alpine Pearls (the result of the EU projects Alps Mobilities I and II, dealing with soft mobility). This cooperation through different kinds of forums also led to many private 
cooperation initiatives in tourism, one of the most prominent being "5 Berge \& Co.". With this card, one can ski in any ski resort, both in the Alps as well as elsewhere (Spain and the USA). Apart from unilateral cooperation, there are also important bilateral projects in tourism, such as Salzalpensteig, a long-distance hiking trail that is built along the historic salt-trading route between Germany and Austria. The salt production and trade is still an important part of the economy but also as a tourism theme in the eastern part of the German Alps.

In order to better understand the destination of the German Alps, the following SWOT analysis has been conducted (Table 1):

Table 1. Strengths, weaknesses, opportunities and threats (SWOT) analysis of the tourism destination of the German Alps.

Strengths Weaknesses

- A balanced and concentrated offer (a bundle of attractions) that combines nature (salt mines, panoramas, landscapes), culture, sport, tradition and good accessibility/infrastructure and leads to a travel decision, as well as a powerful alpine experience

- Wide offer of authentic, regional products

- $\quad$ Diverse outbound markets covered but also strong domestic market, and, consequently, high loyalty

- Tradition (restored authenticity of old cable cars, as an alternative concept for winter tourism development) and nature (the only UNESCO-United Nations Educational, Scientific and Cultural Organization biosphere reserve in Germany and the national park, the mountaineering village of Ramsau)

- Dependency on the weather and shorter season because of the high number of low altitude and relatively small ski centers

- The contrast and the space clash of tourist flows of well-known, mass tourism attractions and high-quality cultural and natural attractions

- Atrophy of the small, private accommodation facilities (many owners quitting the business with no one to take over, or simply renting it long term and not as a hotel facility), as well as fragmentation due to many small owners, a lot of catching up to do in terms of investment especially in the four- and five-star segment
- An authentic interpretation and conservation of natural and cultural heritage for the international market, as well as for the high-price, and quality segment

- Environmentally friendly arrival (an offer that can function without a car)

- With a trend on the German market to make more, shorter, and domestic/regional travel, long-haul travel loses appeal

- Development of sustainable tourism in the small communities to make them livable residential environments and stop the depopulation of these small communities
- Vulnerability to foreign outbound market crashes due to economic and political reasons for top destinations like Garmisch Berchtesgaden or Ammergauer Alpen

- Climate change, snow volatility, and rainy summers (bad weather)

- High traffic volatility (due to the high number of motorized vehicles in the destination) and uneven use of bad capacities

- Shrinking awareness of the importance of tourism, and turning to other economic activities (such as industry)

- The ruining of the natural and cultural landscape

\subsection{Implementation of Sustainable Tourism in the German Alps}

Sustainability in the German Alps is about balance between ecological, economic and social interests. On the one hand, it is important to develop in harmony with nature and the people, while remaining authentic and energy-efficient. On the other hand, economic sustainability means that investments made today should remain functional in the coming generations, in the long term. Sustainability in practice means creating a network of companies working in the field of sustainable economy and jointly promoting environmental awareness. The best way to promote this awareness is by diffusing success stories. They act as role models and evidence that it is possible to follow the sustainability path and be successful. An important impetus for framing and conducting the activities in a sustainable manner comes from EU programs like EU LEADER, where sustainability is a prerequisite and a deciding factor for obtaining the initial financing. 
There are views that sustainability is a bit worn out as a term, because today everybody uses it regardless of whether something is really sustainable, especially politicians. This is why care has to be taken not to overuse this term, as well as to reformulate it for public communication use in order to correspond with people's values. The criticism of the term also includes the fact that it is not a livable thing, but rather a textbook knowledge that has no connection to changes in the tourism market. There are mass tourism destinations in the German Alps, such as Neuschwanstein Castle, where sustainability is not at all of interest to the tourists. However, just a few miles away, in Allgäu, tourists expect untouched nature, a spiritual atmosphere of the monasteries and, of course, sustainability. It is assumed by the tourists that the spiritual atmosphere of the monasteries, untouched nature and sustainable thinking go hand in hand in Allgäu, and the destination is aiming to fulfill these high expectations. There is an overall good public image and support for the values of sustainability locally in the German Alps, but it is very important to understand how much tourists are actually willing to pay for a sustainable destination, and how this readiness changes with the overall economic situation. Public support for sustainable development could be better voiced and translated into action. There is simply a big gap between public discussions, policy and what happens on the grounds, where many people presume that it will not be implemented but simply talked about. A very important consideration in this sense is the relation between organisations governing national parks and tourism organizations, which can often be quite controversial and full of challenges for both sides. National parks might be perceived as being used by the tourism organisation as a marketing tool to attract tourists, while not paying attention to restrictions to which the national park should adhere. More understanding is needed between different stakeholders about mutual responsibilities as well as legal restrictions in using the natural resources.

Sustainable tourism also means making a destination a livable residential environment in the future, while at the same time protecting the nature and farming, with at least the next 20 or 30 years in mind. In this sense, two important aspects are adapting the activities to climate change and to demographic change. However, many local communities in the German Alps are stuck in this "old" way of thinking where the only way to develop a destination is through building a huge infrastructure for alpine ski tourism. These groups are completely unaware of climate change which makes alpine ski tourism less and less profitable even with snow machines. Therefore, more investment is required into communication of the advantages of development without a new ski resort if a destination interprets natural and cultural values in an authentic way.

Careful use and protection of the important natural resources is an important aspect of sustainable tourism. This can be achieved through developing solar parks to use wind energy, using natural gas to power public transportation, and free public transportation to minimize pollution and traffic congestion. Additionally, awareness-raising measures are very important: whether it is about tourist signage in order for the tourists to better understand and value the nature, or about counselling on energy efficiency for the hotels, public relations work and communications are essential parts of sustainable tourism. For organisations such as the Alpine Commission and Alliance in the Alps, sustainability is not just a voluntary concept but an obligation and a primary mission. On this international level, indicators of sustainable tourism are, without question, a very important part of the sustainable tourism policy, unlike single local communities, which sometimes do not need the indicators, and sometimes do not have the resources to gather and use the data.

\subsection{Indicators of Sustainable Development and Sustainable Tourism}

Indicators of sustainable development are a very important concept among professional circles in the German Alps, but at the destination, politics and decision-making are not used very extensively. The framework of the Alpine Convention obliges the communities to integrate indicators of sustainable development in their decision-making; however, without lobbying for this cause and communicating about it, there is little chance of implementing this framework for decision-making. The Alpine Convention is a treaty of eight alpine neighboring countries and it contains various declarations 
and protocols, which cover diverse areas of action in the Alps: transportation, mountain agriculture, forestry, population and culture. Keeping in mind the diversity of the goals, measuring indicators is a very problematic issue in the sense of what is really a priority regarding different indicators. In this sense, lobbying, awareness-raising and best practice examples are equally important in the process of indicator usage.

There are new tourism projects, in which indicators of sustainable development are being more and more used. In fact, funding requirements for different programs, such as LEADER, clearly demonstrate that the sustainability aspect plays a decisive role in granting financing to a particular organization. In this sense, important indicators are: the percentage of regional products, tourism value-added, percentage of employment in hospitality and hotel industry, length of stay, nature protected area and intensity of protection, air quality, accessibility, child-friendliness, tourist satisfaction, the percentage of pastures, and the percentage of domestic animals. There are only a few destinations in the German Alps that actually use the indicators, but the majority agrees that they are important. However, they are not always a viable option for smaller destinations, as the creation requires substantial resources. Some smaller communities have tried to prepare this kind of report only to realize that they lack the resources to do so because it is a demanding task. For protected areas, indicators are included in their plans as a basis for future action, as well as sustainability as a general principle, and tourist organizations are considering collecting and using sustainable development indicators together with market research. It is important for the political decisions to have a basis or support in scientific facts, which is why indicators are important. An approach that is important for controlling the sustainability, apart from indicators of sustainable development in the German Alps, entails the many types of certifications given by different awarding bodies, for different aspects of tourist offer, such as: air spa, adventure destination, accessibility, etc. If a destination for example wants to keep using this type of wording in their marketing, it must pass the certification. However, the problem here is that a destination then focuses only on one or few aspects of tourism at the destination, not on the destination as a whole; such is the case with the indicators of sustainable tourism.

\subsection{Cross-Border Cooperation as an Integral Part of Sustainable Tourism}

There are long-lasting successful stories regarding cross-border cooperation, founded in strong mutual interests, such as a Tirrolean Zugspitz Arena, supported by an EU Interreg funds. Here, communities on both sides of the border (German and Austrian) realized that the Zugspitze, as an outstanding mountain top, presents a mutual resource worth cross-border coordination and mutual long-term planning. In this sense, tourism and mobility planning must follow up on changes in the tourism market, where tourists cross the border on a daily basis, and perceive all sides of the Zugspitze as one destination, not two separate destinations anymore.

Two tourism products are especially profiting from the open-border and active cross-border cooperation: one-day excursions and thematic routes. Thematic routes are deemed especially interesting for cross-border cooperation, because they can span over two-or in some cases even three-countries, bringing diversity and versatility to tourists along the route. Some prominent examples include Via Claudia Augusta (Germany, Austria, Italy), Lechweg and Salzalpensteig (Germany, Austria). These routes are pioneers in the field of visitor management, because they bring unified tourist signage along the route regardless of the country or local community, which is a prerequisite for better communication and consequently more responsible behaviour of the tourists. Cross-border identifies are an important consideration in cross-border cooperation. It is a challenge for local institutions to realize that a tourist from the USA or China does not differentiate between Bavaria, Southeast Bavaria or Austria, and to consequently adapt the tourism policy to create cross-border action spaces which emphasize cultural and historical overlaps of the cross-border regions.

The current situation with the refugee crisis, actually blurs the fact that cross-border cooperation is continually improving. There are some border-crossing closures due to the problems with refugees, and public transportation has been partly affected by these issues. However, these situations are 
temporary in nature and are not influencing the long-term cross-border cooperation. Apart from the refugee crisis, the differences in tourism structure and financing methods are a long-term obstacle for cooperation. In this sense, the desire to cooperate is not questionable but the differences in the resources available to tourism organisations in Austria and Germany are sometimes too vast, such that German partners cannot follow their Austrian partners when it comes to investments. Another problem in the cross-border cooperation presents the fact that EU financing always comes with a huge administrative burden, which builds up new administrative borders. However, it must be said that the EU financing actually presents the German Alps with many different opportunities, especially for projects with a focus on sustainability.

Going beyond solely cross-border cooperation, it is important to also have supranational institutions (such as Alliance in the Alps, the Alpine Commission, etc.) that facilitate the exchange between single destinations, especially those in remote destinations. The goal of these organisations is that no destination is a lone fighter, but that every destination can learn from other destinations and find solutions to its present problems. The most important element in this type of cooperation is for the destinations to find a common theme (such as climate change, demographic change, culture, accessibility, tourism in the public media discourse), share their experiences and learn from the experiences of the other destinations. The second important component, related to the Alpine Commission (which is a body of the Alpine Convention), is that these agreements are obligatory under international law, and sometimes collide with the interests of the local communities, but must nevertheless be respected. The importance of the common problems faced by Alpine communities (such as traffic problems, air pollution, ground erosion and continuation of pastoral farming) is too strong to be jeopardized by any interest a single destination may have.

\subsection{Sustainable Tourism Stakeholders}

Sustainability in the German Alps begins bottom-up and not top-down. It begins with arrival, where sustainable mobilities play an important role, continues with accommodation, where resources should be preserved in the process of providing services, and goes on to regional food and products. All these processes include different kinds of stakeholders. The most important type of tourism stakeholder in the German Alps are accommodation owners, and there is an acute problem with finding a new generation of accommodation owners, which is why the number of beds drops every year. Another problem with stakeholders is the low willingness of different stakeholders (hotels, leisure parks, cable cars, etc.) to work together with tour operators. When it comes to nature-related tourism, institutions such as Berchtesgaden National Park and the German hiking association are investing a great deal of effort in coordinating networks of very diverse stakeholders. Nature sport planners use a specialized software for informing the different stakeholders (bikers, horseback riders, hikers) about the usage of hiking trails and solving potential mutual conflicts. Stakeholder integration is crucial for developing high-quality sustainable tourism products. This way, an entire network of stakeholders can profit from new tourism products and create a "sustainable region." After all, one of the most successful German tourism products—the Romantic Route-started with stakeholders from different parts of southern Germany wanting to turnaround the negative image of post-war Germany. They did so by using culture to facilitate the first cooperation of attractions from two federal states (Bavaria and Baden-Würtemberg) in a time when nobody knew what the word cooperation meant in tourism.

\section{Discussion}

\subsection{Implementation of Sustainable Tourism}

In recent years, special attention has been given to the implementation stage regarding sustainability principles in the field of tourism [34,52,53], because this requires co-operation and combining the resources of many different stakeholders [54]. In the German Alps, the view is that "... 
for us it is important to use the resources, most importantly the natural resources, that we have very carefully", as well as that: " ... it is important to demonstrate the way of valuating and protecting the nature, and communicating this knowledge about nature ... to protect the natural resources, because one wins the acceptance of the guests, but also of the population."

The numerous challenges of the implementation stage of sustainable tourism prevent us from calling any destination definitively sustainable [11]. One of the reasons for this is the inherently fragmented nature of the tourism industry, which is why in many countries there is a need for government to assist not only with setting the policy, but also with implementing the tourism policy [55]. However, according to Yasarata et al. [56], a pressurized political context as well as attitudes and values of the politicians in some countries can significantly alter implementation of sustainable development policies, compared to the original plans. Our interviewee confirms this view by stating that: " $\ldots$ it is the politics that needs to think sustainably, and therefore put the priority on the soft tourism. We are after all only in the second row of this mechanism, and therefore can only really react. The politics acts, and we than react on the decisions." Liburd and Edwards [54] defined the following governmental tasks directly related to implementation: promoting cooperation and coordination, enacting legislation, and education and training. One thing is sure, however, that the implementation of sustainability principles requires a thorough understanding of climate change, global warming, air pollution and water pollution, depletion of ozone, deforestation, biodiversity loss as well as global poverty [57]. This is why diverse case studies of successful implementation of sustainability are needed to highlight the most important issues involved, warn about mistakes made which lead to disastrous consequences, and help with identifying change agents for facilitating and enforcing this change [58]. In this sense, in the German Alps there are views that indicators of sustainable tourism are very hard to implement and therefore: " ... it is sufficient if we raise consciousness of the people, if we praise the best practice examples, if do a good PR for that cause. It is because I find the process of assigning measures and comparisons in order to put in use the indicators seems too ambitious for me."

In order to be effective, implementation of every tourism plan needs to have follow-up and evaluation through mechanisms for continuing feedback [59]. In that sense, they must be evaluated against the triple bottom line, as well as community participation and visitor satisfaction, because otherwise they can easily fail to be implemented, if implementation is not monitored and evaluated [54]. There is a very broad policy deployed in the Bavarian Alps, " . . from water, to mountain forests and to air pollution control. It is actually a whole program, where one has to say: we are very happy that we developed carefully and gently with our regional development program (through the Bavarian national development program-LEP, Landesentwicklungsprogramm), and that we didn't have to concrete the whole parts of land that would then represent a senseless, mono structured places." The tourism policy is also very open to new ideas, as are the indicators, and in that regard one of the interviewees states that " ... there are no indicators that are organized and controlled for, but when we do the market research next year, we will introduce this measure to see which indicators we can regularly control for." The very process of monitoring can sometimes be very hard if the strategy is written vaguely, with no clear targets [19], but ongoing assessment of and feedback on decision-making can be a rich source of new ideas [57] and is an essential part of the collective learning process; this is why it is recognized as one of the basic principles of sustainable development [60]. These feedback loops are important for not staying on the fixed course, but rather being able to learn, change and, consequently, adapt [61]. First of all, feedback supports the evolutionary process of development of the sustainability indicators by discontinuing the usage of rarely used/communicated indicators and fostering the creation of new ones where needed [62]. Secondly, social feedback is crucial for pro-sustainable consumption behavior change, not to become "an exception from everyday life" [63,64]. The UNWTO-United Nations World Tourism Organisation [65] also identified the process of providing feedback to the destination stakeholders in a clear form as one of the most important steps in involving the local community in tourism development. This is why many of the interviewees stressed the importance of working with 
the local farmers, an important part of the local community, in order to preserve the cultural landscape in a traditional way, through alpine farming: “ . . it is for us really important that we motivate this people to continue their activities, because in the moment when the farmers stop to work in this area, and to do something like this it will be tough. Then, the same will happen as in the South Tirol that no one takes care anymore of this cultural landscape. Then, this landscape will be completely ruined."

\subsection{Indicators of Sustainable Development and Sustainable Tourism}

Hall [30] sees tourism policy as a result of compromise between ideas, values and interests, which leads to the adoption of a strategy, action or product by government. Apart from that, the tourism policy values also need to reflect the changing values among the travelling public because they are profoundly influencing the motivation to travel [13]. This is an important addition, because some local communities: "cannot imagine that there is a tourism future without a new ski resort ..." , and also because "... the designing of this transition away from the classical alpine tourism towards the individually configured winter sports offer is surely a risky endeavor, because many big hoteliers are used to alpine ski tourists." Prideaux [3] suggests that innovation has to be a core value for planning and product development for the destination to be able to survive in the global environment. More specifically, in the mountain destinations, the author names planning philosophy as one of the main factors of success. In this sense, indicators of sustainable tourism are one of the main fields of research and innovation in tourism policy $[11,54,66,67]$. This view has also been confirmed by our interviewees in the sense that: "for some projects, this type of indicators are being more and more used. However, we ourselves actually do not have this basis for policy decision making." Another interviewee states that: "In the communication with politics and with decision-makers, this is an absolutely humorous argument to understand, however it has been better and better understood, or the urgency is becoming more and more obvious." The important aspect about sustainability indicators is that they should always represent stakeholder values [68]. This view has also been confirmed by our interviewee: "In that sense, one has to definitely reformulate sustainability in the public communication and explain it using different words, in order for the sustainability to reflect where the value lies for a particular person."

\subsection{Cross-Border Cooperation in the German Alps}

Cross-border cooperation is still an underresearched area, but with vast importance in a setting such as Europe, where national borders make up an important part of the institutional setting [69]. Tourism, and especially sustainable tourism, are part of a complex system, which is why one must always look beyond current destination borders to ensure future development [70]. As our interviewee confirms: “ . . our guests definitely move outside of the political borders. It doesn't matter if it is Germany or Austria, and therefore I think this cross-border cooperation is very important. We are trying accordingly to implement more and more projects together. This is not only because of the EU financing programs, but because we can see here at our destination that the guests are moving towards Austria very naturally." Sustainable development is inextricably connected to international development and cross-border cooperation, since complex issues like environmental degradation can only be tackled through supranational initiatives, shared objectives and networking [71]. This is why organisations like Alliance in the Alps have been initiated, in order to " ... have this exchange, which can connect the Alps and the single communities. We are looking very favourably on the connecting elements between the single regions and the single communities. We want to avoid the situation that every community in the Alps is a lone fighter, and this way every community in the Alps can find its own solution to the present problems." Sustainability of the EU depends on the cooperation of the neighbouring countries, which is why cross-border cooperation has been used as an important tool to promote and advance sustainability principles among EU member countries [44]. However, our research showed that there is also some criticism of the EU cross-border financing, in the sense that: "... everything that is nowadays connected with the EU financing is practically always 
with this big Bureaucratic burden which again build up the borders, although we all want them torn down. The bureaucratic burden behind it is difficult." In the literature, this question of the degree of formalisation of cross-border governance systems is an important consideration, keeping in mind that it can vary considerably, from rigidly institutionalized to more informal solutions [72]. The best solution in this sense is to support organization variety in the sense that there should be institutionalized organizations, territorially oriented organizations, as well as functionally oriented ones.

\subsection{Sustainable Tourism Stakeholders}

Tourism is a people's business and it is important to systematically identify all stakeholders and their perceptions as a first step in the process, as well as to enhance stakeholders' knowledge about sustainable tourism [73]. In that sense, there are destinations in the German Alps that are trying hard to implement sustainable tourism: "We are now in the process of building a suitable partner network, where a whole region can profit from it economically, from this whole sustinable thinking, and this network which characterizes the whole thing ... we want to create a network of many companies that work in the field of sustainable economy, and promote it that way as a sustainability region." Well-informed stakeholders are crucial for accepting, planning, lobbying for, participating in and managing sustainable tourism [55]. This is why it is important that the destinations "... work very strongly with nature conservation asociations and environmental educators. We have different networks in the field of environmental education, and we work together with them." An important aspect is also to "... link up the offer more strongly, so that not everybody does its own separate development or makes a separate offer, but that the operations are being continued in a more cooperative way." There are two important issues related to stakeholder engagement in the destination: power relationships and leadership approach, both of which have not been sufficiently researched in the academic literature [74], and are very alive in the German Alps in the sense that: " ... tourism in Bavaria is very political ..." ", and that politicians often say "I cannot commit myself to strongly to tourism because than I will not get reelected, because stakeholder XZ is against it."

\section{Conclusions}

Achieving competitiveness of a destination without sustaining it is not a goal worth pursuing, which is why concepts of sustainable and resilient destinations are so important. The destination of the future will have to be sustainable (adhering to the principles of sustainability) and resilient (planning for crisis management) in order to remain competitive in the global market in the long term. It is important for the destination to recognize crisis as a chance for improvement if planned for and managed properly, and to acknowledge its own carrying capacity limits, in terms of available resources. Critical in this quest is adaptive destination governance as a way of dealing with ever-increasing change in the global environment. One track of governance is crisis management, which is best suited for rapid, sudden changes; the other track is sustainability, which is best suited for dealing with incremental, gradual changes and their long-term effects. The results of our research demonstrate that tourism policy, being a fragmented, interdisciplinary policy, has similar characteristics to sustainability policy, which makes it suitable for tourism and sustainability to go hand in hand, but makes it no easier to implement such complex, interdisciplinary policies. It starts with setting the indicators, collecting the data, to pushing the agenda in public discussion and on the political level, all the way to introducing the institutional and societal change and obtaining the feedback.

It is important that each decision about the destination is well thought out, keeping in mind the question: what will be the total future effects/consequences of this decision in a wide range of fields? The answer to this question depends on the ability of the decision makers to be informed, make informed decisions, and take corrective actions based on interdisciplinary, interactive process and not function as a one-way street or focusing on one narrow line of thought. However, it should be well thought out at which level the complex concepts such as indicators of sustainable development should be implemented, because the research results show undoubtedly that local tourism organizations lack 
the resources and skills to apply such tools. Destinations would benefit greatly from having these kinds of tools available, so these types of reports should be prepared on a higher regional/national level in order to support the decision-making in the local destinations. These types of reports would help in dealing with issues beyond just tourism, but would be beneficial for many other aspects of local societies and ecosystems.

The dismantling of the borders inside of the EU opened up new undiscovered markets for thematic routes and excursions to neighbouring destinations. However, destination management adapted to this new situation quite differently: while in some destinations new institutional arrangements are being created to create umbrella tourism brands and fully use the possibilities, in other destinations, crossing the national border in search for partners is neither desired nor implemented. In this sense, the importance of cross-border cooperation in the EU mountain destinations can never be overvalued. Even organizations that have administrative problems with using the EU funds state that they are better off with these funds than without them.

Stakeholders with the sufficient knowledge and skills to be active participants in the change process are of crucial importance for implementing sustainability as a concept. This is why a mountain destination has to devote plenty of resources to creating networks of sustainability stakeholders that work together with shared objectives and values. Only in this way can a destination move forward from the old development concepts such as new alpine ski resorts and massive investments in infrastructure.

Climate change is occurring and should be dealt with in the same manner as the demographic change, in the sense that trends should be identified and business and public decisions adapted accordingly. Less $\mathrm{CO}_{2}$ will not mean stopping climate change, because climate is not influenced by anthropogenic factors alone, but it is a very complex phenomenon with only one constant aspect, which is change. However, $\mathrm{CO}_{2}$ and other greenhouse gases affect the climate but, more importantly, they also affect public health. Climate change brings many challenges for global society, thus the global society will have to adapt to change and try to mitigate the negative effects of these changes.

Mutual competition and knowledge transfer occur only among Alpine destinations, which can affect innovativeness. Bearing in mind the leading market position of the Alps with respect to mountain tourism, most of the exchange would be about transferring the knowledge to less-developed destinations. However, the opportunity to learn from other European destinations, and then develop and innovate the offer, also stands for Alpine destinations, notwithstanding their leading market position. The outbound market of the Alpine region is very strong, but the offer can always be enhanced, especially through innovation and applying the best case practices from other European mountain chains, such as the Tatra, Pyrinees, Rhodopes or Dinarides.

Acknowledgments: The authors give special thanks to Anna Scuttari and Harald Pechlaner for helping with the questionnaire design. This study was financed by the Deutsche Bundesstiftung Umwelt through Research Grant No. 30015/542, "Nachhaltiger Bergtourismus in den Alpen und den Dinariden".

Author Contributions: Ivan Paunović and Verka Jovanović conceived and designed the interviews, Ivan Paunović conducted the interviews and analyzed the data, Ivan Paunović and Verka Jovanović wrote the paper together.

Conflicts of Interest: The authors declare no conflict of interest. The founding sponsors had no role in the design of the study, in the collection, analyses, or interpretation of data, in the writing of the manuscript, and in the decision to publish the results.

\section{References}

1. Hall, M.C. Policy Learning and policy failure in sustainable tourism governance: From first and second order to third order change? J. Sustain. Tour. 2011, 19, 649-671. [CrossRef]

2. Diaz, M.R.; Rodriguez, T.F.E. Determining the Sustainability Factors and Performance of a Tourism Destination from the Stakeholders' Perspective. Sustainability 2016, 8, 951. [CrossRef]

3. Prideaux, B. Resort Destinations-Evolution, Management and Development; Elsevier: Oxford, UK, 2009.

4. Byrd, E.T. Stakeholders in Sustainable Tourism Development and their Roles: Applying Stakeholder Theory to Sustainable Tourism Development. Tour. Rev. 2007, 62, 6-13. [CrossRef] 
5. Aall, C. Sustainable Tourism in Practice: Promoting or Perverting the Quest for a Sustainable Development? Sustainability 2014, 6, 2562-2583. [CrossRef]

6. Krippendorf, J. Für einen ganzheitlich-orientierten Tourismus. In Für Einen Anderen Toruismus; Frankfurt am Main, Fischer Taschenbuch Verlag: Berlin, Germany, 1988; pp. 18-28.

7. Orlovic-Lovren, V.; Crncevic, T.; Milijic, S. Tourism Development in Serbia-on the Way to Sustainability and European Integration. SPATIUM Int. Rev. 2013. [CrossRef]

8. United Nations World Tourism Organisation. Davos Declaration Climate Change and Tourism Responding to Global Challenges; United Nations World Tourism Organisation: Davos, Switzerland, 2007.

9. Hall, C.M. Changing paradigms and global change: From sustainable to steady-state tourism. Tour. Recreat. Res. 2010, 35, 131-143. [CrossRef]

10. Hall, C. Degrowing tourism: Decroissance, sustainable consumption and steady-state tourism. Anatolia 2009, 20, 46-61. [CrossRef]

11. Weaver, D. Sustainable Tourism, 1st ed.; Butterworth-Heinemann, Elsevier: Oxford, UK, 2006.

12. Bramwell, B.; Lane, B. Getting from here to there: Systems change, behavioural change and sustainable tourism. J. Sustain. Tour. 2013, 21, 1-4. [CrossRef]

13. Boniface, B.; Cooper, C. Worldwide Destinations: The Geography of Travel and Tourism; Elsevier: Oxford, UK, 2009.

14. Candela, G.; Figini, P. The Economics of Tourism Destinations; Springer: Berlin/Heidelberg, Germany, 2012.

15. Vanhove, N. The Economics of Tourism Destinations; Elsevier: Oxford, UK, 2005.

16. Fennell, D. Ecotourism Programme Planning; CABI Publishing: Wallingford, UK, 2002.

17. Drumm, A.; Moore, A. An Introduction to Ecotourism Planning; The Nature Conservancy: Arlington, VA, USA, 2005.

18. Godde, P.; Price, M.; Zimmermann, F. Tourism and development in mountain regions: Moving forward into the new millennium. In Tourism and Development in Mountain Regions; CABI Publishing: Wallingford, UK, 2000; pp. 1-26.

19. Veal, J. Leisure and Tourism Planning and Policy, 2nd ed.; CABI Publishing: Oxford, UK, 2002.

20. Wanda, G.E. Rural Tourism Development Localism and Cultural Change; Channel View Publications: New York, NY, USA, 2009.

21. Fennell, D. Ecotourism; Taylor \& Francis: New York, NY, USA, 2007.

22. Tribe, J. The Economics of Recreation, Leisure and Tourism; Elsevier: Oxford, UK, 2011.

23. Dodds, R.; Butler, R. Barriers to implementing sustainable tourism policy in mass tourism destinations. Tourismos 2010, 5, 35-53.

24. Saarinen, J. Critical Sustainability: Setting the Limits to Growth and Responsibility in Tourism. Sustainability 2014, 6, 1-17. [CrossRef]

25. Wearing, S.; Neil, J. Ecotourism: Impacts, Potentials and Possibilities? Elsevier: Oxford, UK, 2009.

26. Ateljevic, J.; Lan, L. Tourism Entrepreneurship-Concepts and Issues. In Tourism and Entrepreneurship-International Perspectives; Elsevier: Oxford, UK, 2009; pp. 9-32.

27. Go, F. Selling Canada. Travel Tour. Anal. 1987, 12, 17-29.

28. United Nations Environment Programme; World Tourism Organization. Quebec Declaration on Ecotourism; United Nations Environment Programme: Nairobi, Kenya; World Tourism Organization: Madrid, Spain, 2002.

29. Estol, J.; Font, X. European tourism policy: Its evolution and structure. Tour. Manag. 2016, 52, $230-241$. [CrossRef]

30. Hall, C.M. Tourism Planning-Policies, Processes and Relationships, 2nd ed.; Pearson Education Limited: Dorchester, UK, 2008.

31. Gössling, S.; Hall, M.C.; Ekström, F.; Engeset, A.B.; Aall, C. Transition management: A tool for implementing sustainable tourism scenarios. J. Sustain. Tour. 2012, 20, 899-916. [CrossRef]

32. Ruhanen, L. Local government: Facilitator or inhibitor of sustainable tourism development? J. Sustain. Tour. 2013, 21, 80-98. [CrossRef]

33. Dabphet, S.; Scott, N.; Ruhanen, L. Applying diffusion theory to destination stakeholder understanding of sustainable tourism development: A case of Taiwan. J. Sustain. Tour. 2012, 20, 1107-1124. [CrossRef]

34. Waligo, V.M.; Clarke, J.; Hawkins, R. Implementing sustainable tourism: A multi-stakeholder involvement management framework. Tour. Manag. 2013, 36, 342-353. [CrossRef] 
35. Caruana, R.; Glozer, S.; Crane, A.; McCabe, S. Tourists' accounts of responsible tourism. Ann. Tour. Res. 2014, 46, 115-129. [CrossRef]

36. Van der Sanden, M.C.A.; Meijman, F.J. A step-by-step approach for science communication practitioners: A design perspective. J. Sci. Commun. 2012, 11, 317-331.

37. Spangenberg, J.H. Sustainability Science: A Review, an Analysis and Some Empirical Lessons. Environ. Conserv. 2011, 38, 275-287. [CrossRef]

38. Hak, T.; Janouskova, S.; Whitby, A.; Abdallah, S.; Kovanda, J. Indicator Policy Factsheet: A Knowledge Brokerage Tool. Sustainability 2015, 7, 3414-3429. [CrossRef]

39. Popesku, J. Menadžment Turističke Destinacije; Singidunum University: Belgrade, Serbia, 2011; p. 286.

40. Lundquist, K.; Trippl, M. Towards Cross-Border Innovation Spaces. A Theoretical Analysis and Empirical Comparison of the Öresund Region and the Centrope Area; SRE-Discussion Papers; WU Vienna University of Economics and Business: Vienna, Austria, 2009.

41. Dredge, D.; Jamal, T. Mobilities on the Goald Coast, Australia: Implications for destination governance and sustainable tourism. J. Sustain. Tour. 2013, 21, 557-579. [CrossRef]

42. Zillinger, M. Tourist routes: A time-geographical approach on German car-tourists in Sweden. Int. J. Tour. Space Place Environ. 2007, 9, 64-83. [CrossRef]

43. Ioannides, D.; Nielsen, P.; Billing, P. Transboundary Collaboration in Tourism: The Case of the Bothnian Arc. Tour. Geogr. 2006, 8, 122-142. [CrossRef]

44. Stojkov, B.; Nikolov, A. Cultural cross-border co-operation among Balkan's countries with the case of Serbia and Bulgaria. Bull. Serbian Geogr. Soc. 2008. [CrossRef]

45. Freeman, R.E. Strategic Management: A stakeholder Approach; Pitman: Boston, MA, USA, 1984.

46. Jamal, T.B.; Getz, D. Collaborative Theory and Community Tourism Planning. Ann. Tour. Res. 1995, 22, 186-204. [CrossRef]

47. Byrd, E.T.; Cardenas, D.A.; Greenwood, J.B. Factors of Stakeholder Understanding of Tourism: The Case of Eastern North Carolina. Tour. Hosp. Res. 2008, 8, 192-204. [CrossRef]

48. Pechlaner, H.; Zacher, D.; Paunovic, I. Touristische Stakeholder in der zweiten Reihe. In Gesellschaftlicher Wandel als Hearausforderung im Alpinen Tourismus; Erich Schmidth Verlag: Berlin, Germany, 2016; pp. $79-97$.

49. Pike, S.; Page, S. Destination Marketing Organizations and destination marketing: A narrative analysis of the literature. Tour. Manag. 2014, 41, 202-227. [CrossRef]

50. Jennings, G.R. Interviewing: A Focus on Qualitative Techniques. In Tourism Research Methods: Intergrating Theory with Practice; Brent, W.R., Peter, B., Catherine, P., Eds.; CABI Publishing: Oxfordshire, UK, 2005; pp. 99-115.

51. Smith, S.L.J. Practical Tourism Research; CABI: Oxfordshire, UK, 2012.

52. Connell, J.; Stephen, J.P.; Bentley, T. Towards Sustainable Tourism Planning in New Zealand: Monitoring Local Government Planning under Resource Management Act. Tour. Manag. 2009, 30, 867-877. [CrossRef]

53. Butcher, J. The Myth of Agency through Community Participation in Ecotourism. In Tourism Development Growth, Myths and Inequalities; CABI Publishing: Oxfordshire, UK, 2008; pp. 11-27.

54. Liburd, J.J.; Edwards, D. Understanding the Sustainable Development of Tourism; Goodfellow Publishers Limited: Oxford, UK, 2010.

55. Edgell, D.L.S.; Allen, M.D.; Smith, G.; Swanson, J.R. Tourism Policy and Planning Yesterday, Today and Tomorrow; Elsevier: Oxford, UK, 2008.

56. Yasarata, M.; Altinay, L.; Burns, P.; Okumus, F. Politics and Sustainable Tourism Development-Can They Co-Exist? Voices from North Cyprus. Tour. Manag. 2010, 31, 345-356. [CrossRef]

57. Sloan, P.; Legrand, W.; Chen, J. Sustainability in the Hospitality Industry; Elsevier: Oxford, UK, 2009.

58. Munjal, S.; Munjal, P.G. Sustainable Tourist Destinations: Creation and Development. In Managing Sustainability in the Hospitality and Tourism Industry Paradigms and DIrections for the Future; Taylor \& Francis Group: Boca Raton, FL, USA, 2014; pp. 227-272.

59. Goeldner, C.R.; Ritchie, J.R.B. Tourism Principles, Practices, Philosophies, 1st ed.; John Wiley \& Sons, Inc.: Hoboken, NJ, USA, 2009.

60. International Institute for Sustainable Development. Assessing Sustainable Development Principles in Practice; International Institute for Sustainable Development: Winnipeg, MB, Canada, 1997.

61. Middleton, A. Managing Ecological Balance. In Sustainability in Tourism; Springer Gabler: Wiesbaden, Germany, 2013; pp. 137-157. 
62. Morse, S. Developing Sustainability Indicators and Indices. Sustain. Dev. 2015, 23, 84-95. [CrossRef]

63. Juvan, E.; Dolnicar, S. The attitude-behaviour gap in sustainable tourism. Ann. Tour. Res. 2014. [CrossRef]

64. Miller, G.; Rathouse, K.; Scarles, C.; Holmes, K.; Tribe, J. Public Understanding of Sustainable Tourism. Ann. Tour. Res. 2010, 37, 627-645. [CrossRef]

65. United Nations World Tourism Organization. Indicators of Sustainable Development for Tourism Destinations; United Nations World Tourism Organization: Madrid, Spain, 2004.

66. Jauhari, V. Managing Sustainability in the Hospitality and Tourism Industry; Apple Academic Press Inc.: Oakville, ON, Canada, 2014.

67. Jenkins, I.; Schröder, R. Sustainability in Tourism; Springer Fachmedien: Wiesbaden, Germany, 2013.

68. Meadows, D. Indicators and Information Systems for Sustainable Development: A Report to the Balaton Group; Hartland Four Corners: Hartland, VT, USA, 1998.

69. Pechlaner, H.; Jochmann, J. Grenzüberschreitende Kooperationen im Tourismus; Hubert \& Co.: Göttingen, Germany, 2014; pp. 5-7.

70. Farrell, B.; Twinning-Ward, L. Reconceptulizing tourism. Ann. Tour. 2004, 31, 274-295. [CrossRef]

71. Schenone, C.; Brunenghi, M.M.; Pittaluga, I.; Hajar, A.; Kamali, W.; Montaresi, F.; Rasheed, M.; Wahab, A.A.; Moghrabi, Y.E.; Manasrah, R.; et al. Managing European Cross Border Cooperation Projects on Sustainability: A Focus on an MESP Project. Sustainability 2017, 9, 112. [CrossRef]

72. Zumbusch, K.; Scherer, R. Cross-Border Governance: Balancing Formalized and Less Formalized Co-Operations. Soc. Sci. 2015, 4, 499-519. [CrossRef]

73. Byrd, E.T.; Gustke, L. Using decision trees to identify tourism stakeholder: The case of two Eastern North Carolina counties. Tour. Hosp. Res. 2007, 7, 176-193. [CrossRef]

74. Kennedy, V.; Augustyn, M.M. Stakeholder power and engagement in an English seaside context: Implications for destination leadership. Tour. Rev. 2014, 69, 187-201. [CrossRef]

(C) 2017 by the authors; licensee MDPI, Basel, Switzerland. This article is an open access article distributed under the terms and conditions of the Creative Commons Attribution (CC BY) license (http:/ / creativecommons.org/licenses/by/4.0/). 